"An empirical investigation of market timing behavior: evidence from Indian IPOs"

\begin{tabular}{|c|c|c|}
\hline AUTHORS & \multicolumn{2}{|l|}{ Manas Mayur } \\
\hline ARTICLE INFO & \multicolumn{2}{|c|}{$\begin{array}{l}\text { Manas Mayur (2016). An empirical investigation of market timing behavior: } \\
\text { evidence from Indian IPOs. Investment Management and Financial Innovations, } \\
\text { 13(3), 84-92. doi:10.21511/imfi.13(3).2016.07 }\end{array}$} \\
\hline DOI & \multicolumn{2}{|c|}{ http://dx.doi.org/10.21511/imfi.13(3).2016.07 } \\
\hline RELEASED ON & \multicolumn{2}{|l|}{ Tuesday, 23 August 2016} \\
\hline JOURNAL & \multicolumn{2}{|c|}{ "Investment Management and Financial Innovations" } \\
\hline FOUNDER & \multicolumn{2}{|c|}{ LLC "Consulting Publishing Company "Business Perspectives" } \\
\hline & & $\begin{array}{l}=-z \\
=z\end{array}$ \\
\hline NUMBER OF REFERENCES & NUMBER OF FIGURES & NUMBER OF TABLES \\
\hline 0 & 0 & 0 \\
\hline
\end{tabular}

(C) The author(s) 2022. This publication is an open access article. 
Manas Mayur (India)

\title{
An empirical investigation of market timing behavior: evidence from Indian IPOs
}

\begin{abstract}
The purpose of this paper is to investigate the market timing behavior of issuers of Indian Initial Public Offerings (IPOs). It was found that investor's expectation that earnings growth will continue after IPO were not even sustained in post IPO period. The constant decline in P/E and M/B suggested that firms took advantage of over-optimism of investors. The deterioration in post IPO performance show that issuer took benefit of pre IPO profit margin knowing that the level would not be continued in the future. Considering that the issuers took advantage of favorable market condition, a multivariate analysis was carried out to examine whether issuers tried to maximize their proceeds through IPO or not. The idea is that any market timing aspect should get reflected in the effort to maximize proceeds in the favorable market condition. The result based on multivariate regression suggest that market timers, identified as firms that go public when the market is hot, tried to maximize the total proceeds at the time of IPO. The hot issue market effect was remarkably robust; it was significant for both firm and industry-level characteristics.
\end{abstract}

Keywords: market timing, India, Initial Public Offerings, Hot issue market.

JEL Classification: G10, G11, G12, G14.

\section{Introduction}

Market timing aspect has attracted many researchers ever since Ibbotson and Jaffe (1975) documented the concept of "Hot issue market". The nature of market affects many of the corporate decisions, specially related to financing decisions. There is a recent trend that has been observed by researchers that entrepreneurs try to time their public issue with the Hot issue market. In fact, timing the issue with Hot issue market has become a key to a successful Initial Public Offering (IPO). But what has puzzled researchers so far is how to accurately measure the period as Hot issue market.

Most of the studies on market timing estimated Hot issue market by establishing relationship between high volume of IPO numbers and high initial return and asserted that the market timing effort should be reflected in the degree of positive correlation between the two, i.e., more is the number of IPOs followed by high initial return more is the possibility that issuers timed their issue. While this gives a strong indication on possibility of market timing effort, yet, I felt that it might not explain the effort completely. I am convinced by the fact that issuers wait for the right opportunity when the market sentiment is favorable which can very well be reflected by the high initial return from the issues. A favorable market attracts many issuers and, hence, leads to increase in the volume of IPOs. But what motivated us to explore this issue further was to examine if firm's internal status was responsible for market timing effort or not. Therefore, I not only try to evaluate whole market as

(C) Manas Mayur, 2016.

Manas Mayur, Dr., Assistant Professor, Accounting and Finance Department, Goa Institute of Management, Goa, India. a measure and motivation for timing the issue, but also the position of firm with respect to market as a motivation for timing the issue. I made an attempt to study if issuers actually timed their issue when the financial status of their firms was at peak or not.

In order to analyze whether issuers took advantage of their peak position or not, I have carried out a univariate analysis where trend in variables reflecting investor's sentiments and expectation are examined in post IPO period. The results suggested that investor's expectation that earnings growth will continue after IPO were not even sustained in post IPO period. The constant decline in $\mathrm{P} / \mathrm{E}$ and $\mathrm{M} / \mathrm{B}$ suggest that firms took advantage of over-optimism of investors. In order to see whether company took benefit of their pre IPO profit margin or not Ihave made an attempt to compare pre IPO performance with post IPO performance. The deterioration in post IPO performance shows that issuer took benefit of pre IPO profit margin knowing that the level would not be continued in the future. Considering that the issuers took advantage of favorable market condition, I conducted a multivariate analysis to examine whether issuers tried to maximize their proceeds through IPO or not. I examined 306 firms that went for IPO between 1997 and 2007. Depending on the prevailing market condition the complete time period is divided into two, Hot market and Cold market. I, then, try to investigate whether firms tried to maximize their proceeds during period when market was unusually high (Hot market) or not. The idea is that any market timing aspect should get reflected in the effort to maximize proceeds in the favorable market condition.

The findings of this study will be particularly helpful in understanding the IPOs of Indian firms. Though the similar studies done in context of 
developed economies provide some insight on the issue, yet, extrapolating the results of those studies directly onto Indian scene may not be correct. Ghosh (2005) conducted his study on Indian IPOs wherein he tried to investigate whether Indian IPO volumes can be determined by initial average return of IPOs or not. He found that there was no significant relation between IPO volume and initial returns during Hot and Cold a market which was on a contrary to the results of studies on developed nation (Ibbotson and Jaffe, 1975; Ritter, 1984; Ritter and Sindelar, 1988; Lowry and Schwert, 2002, etc). I am extending his analysis through entirely different approach.

The remaining of this paper is organized as follows. Section 1 provides a brief literature review and hypotheses development. Section 2 describes the methodology used in this paper. Section 3 discusses and final section makes the concluding remarks.

\section{Hypotheses development}

Most of the studies on market timing estimated Hot issue market by establishing relationship between high volume and high initial return and asserted that the market timing effort should be reflected in the degree of positive correlation between the two, i.e., the more is number of IPOs followed by high initial return the more is possibility that issuers time their issue. While this gives a strong indication on possibility of market timing effort, yet, I felt that it might not explain the effort completely. I am convinced by the fact that a lots of companies wait for right opportunity. But what motivated us to explore this issue further was to examine if firm's internal status was responsible for market timing effort or not. Therefore, I not only try to evaluate whole market as a measure and motivation for timing the issue, but also the position of firm with respect to market as a motivation for timing the issue. I made an attempt to study if issuers actually timed their issue when the financial status of their firms was at peak or not. The testable research hypotheses of our research are:

$H 1$ (a): There is a significant decline in earning potentials of the firms in post IPO period.

$H 1$ (b): There is a significant decline in operating performance of the firms in post IPO period.

H1 (c): Total IPO proceeds in HOT issue market significantly differs from total IPO proceeds in

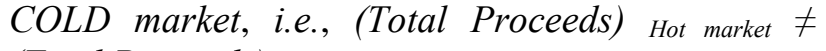
(Total Proceeds) Cold market

\section{Methodology}

1.1. Sample and data. The sample for the study was derived from 542 firms that went public between 2002 and 2012. The annual trend in the number of IPOs and capital raised by Indian firms through IPOs are shown in Table 1. Year 2005-2006 received the maximum number of IPOs in our sample followed by an equivalent optimism by investors and issuers in following two years. The peaking up of boom was followed up by burst during 2008-2009 wherein all major stock markets suffered huge losses.

Table 1. Number of IPOs and amount raised by Indian companies from 2002 to 2012

\begin{tabular}{|c|c|c|}
\hline Year & No. of issues & Amount (Rs. Cr) \\
\hline $2002-03$ & 6 & 1,039 \\
\hline $2003-04$ & 28 & 17,807 \\
\hline $2004-05$ & 29 & 21,432 \\
\hline $2005-06$ & 102 & 23,676 \\
\hline $2006-07$ & 85 & 24,993 \\
\hline $2007-08$ & 90 & 52,219 \\
\hline $2008-09$ & 21 & 2,034 \\
\hline $2009-10$ & 44 & 46,941 \\
\hline $2010-11$ & 57 & 46,182 \\
\hline $2011-12$ & 36 & 23,982 \\
\hline $2012-13$ & 44 & 34,313 \\
\hline
\end{tabular}

Source: Prime database.

I have compiled firm level data from Prowess, a database provided by the Centre for Monitoring the Indian Economy (CMIE). I have dropped those firms for which data were not available for all the time windows. The methodology required data from one year before IPO to two years after the IPO. Therefore, firms that went public after 2012 were also not included in the sample as for them the data for next two years would not be available. The final sample of this study consisted of 306 firms.

\section{Measures}

\section{Market expectations and performance measures}

Investors' expectations are measured by Market-toBook ratio (M/B) and Price-to-Earnings ratio. Another ratio Earning-Per-Share (EPS) was also examined to measure the post issue earnings performance. Since IPO firms are not publicly traded at Y-1, the ratios were compared for following two time windows only: (i) IPO year to one year after IPO $(\mathrm{Y}+1)$, and (ii) IPO year to two year after IPO $(\mathrm{Y}+2)$.

Operating performance is measured by operating return on total assets (PBDIT/TA) and cash flow from operating activities divided by total assets $(C F / T A)$. Operating return on total assets is used as a measure of efficiency of assets utilization. Cash flow from operating activities is used, because it is a primary component in net present value (NPV) calculations that is used to value a firm. Earlier studies like Jain and Kini (1994) used asset turnover ratio as a measure of performance. I felt that asset 
turnover ratio is a weak proxy for operating performance. A company with high profit margins can generate significant profit even with low asset turnover ratio. Hence, I have not used the variable as a performance variable in present study.

\section{Market timing measures}

Estimation of Hot and Cold issue market is adapted from Alti (2006). Hot issue market and Cold issue market are defined on the basis of the monthly IPO volume. Month wise IPO data were extracted from CMIE Prowess. In order to smooth out seasonal variation, 6-month centered moving average of the number of IPOs for each month was calculated. The monthly moving average IPO volume was, then, detrended. The detrended monthly moving average IPO volume from 1997 to 2007 is plotted in Figure 1. The horizontal line is the mean at 3.96. Hot (Cold) months are, then, defined as the period that is above (below) the mean of the distribution of the detrended monthly moving average IPO volume. A dummy variable HOT has been created which takes the value 1 if the IPO is in hot month.

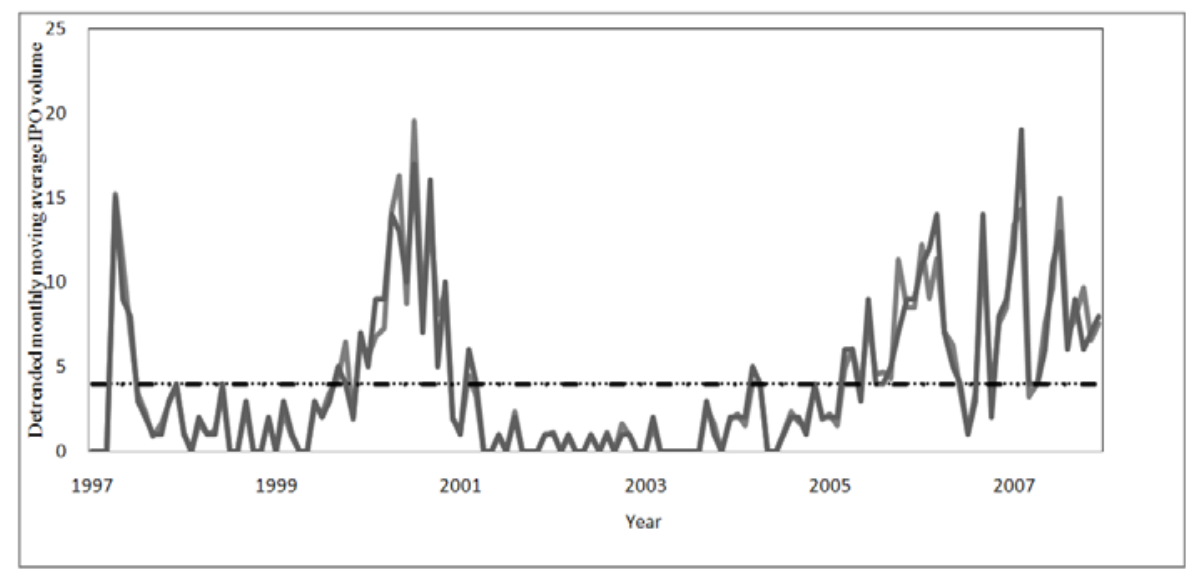

Fig. 1. Time series of de-trended monthly moving average IPO volume

Table 2. Definitions of firm-specific variables used in this study

\begin{tabular}{|l|l|}
\hline \multicolumn{1}{|c|}{ Variables } & \multicolumn{1}{c|}{ Definition } \\
\hline CF/TA & $\begin{array}{l}\text { Ratio of cash flow from operations and total assets. Cash flow from operations indicates cash generated through the main } \\
\text { operations of the company. Total assets include value of fixed assets, investments and current assets. }\end{array}$ \\
\hline PBDIT/TA & $\begin{array}{l}\text { Ratio of profit before depreciation interest and tax and total assets. Total assets include value of fixed assets, investments and } \\
\text { current assets. }\end{array}$ \\
\hline SALES & $\begin{array}{l}\text { By sales I meant income generated from main business activities like sale of goods and services, fiscal benefits, trading } \\
\text { income. It also includes internal transfers. }\end{array}$ \\
\hline P/E & Annual mean daily closing stock price divided by operating earningsper share. \\
\hline$M / B$ & $\begin{array}{l}\text { Ratio of market value to book value. Market value is calculated as annual mean daily closing price. Book value is calculated as } \\
\text { the sum of the equity capital and reserves less revaluation reserves divided by outstanding number of shares. }\end{array}$ \\
\hline EPS & $\begin{array}{l}\text { Earning per share is defined as the ratio of the profit after tax net of non-recurring transactions of the company in the most } \\
\text { recent 12 month period to the number of shares outstanding as on that date }\end{array}$ \\
\hline Size & Size is defined as total assets of the company which include value of fixed assets, investments and current assets. \\
\hline Sgrw & $\begin{array}{l}\text { Sales growth is a measure of growth potential of a company. This variable is measured by calculating annual percentage } \\
\text { increase in sales. }\end{array}$ \\
\hline Intang & Intangible assets of the firm. \\
\hline D/E & $\begin{array}{l}\text { Debt-Equity ratio is a measure of the financial leverage of a company. This ratio is calculated by dividing total borrowings of a } \\
\text { firm by net worth. }\end{array}$ \\
\hline
\end{tabular}

\section{Results and discussion}

3.1. Summary statistics. Summary statistics of firm specific variables are reported in Table 3. The summary statistics are reported for: IPO Year $(\mathrm{Y}+0)$, one year after IPO $(\mathrm{Y}+1)$, and two years after IPO $(\mathrm{Y}+2)$. The mean scores of price-toearnings ratio $(P / E)$ initially increased from IPO year to +1 year, but, then, decreased in +2 year after the IPO year. The mean score for the time windows are $37.88,54.36$ and 30.93 . The median score for the same time windows are 20.8, 16.40 and 12.79. The median decreased consistently after the IPO.
Mean score of market-to-book ratio $(M / B)$ of the firms in the IPO year is 4.69. It decreased to 3.17 in IPO+1 year and 2.07 in IPO+2 year. The median score decreased from 3.44 in IPO Year to 1.93 in the IPO+1 year and, then, decreased to 1.68 in two years after the IPO.

The earnings of firms are captured through earnings per share $(E P S)$. The decreasing trend in mean and median score of EPS showed that firm's earnings decreased after the IPO. Where the mean score decreased from 22.45 to 12.72 , median score decreased from 16.29 to 5.42 . 
Table 3. Summary statistics

\begin{tabular}{|c|c|c|c|c|c|c|}
\hline Variables & Market condition & Time window & $n$ & Mean & Median & S.D. \\
\hline \multirow{8}{*}{ PBDIT/TA } & \multirow{4}{*}{ Hot } & $Y-1$ & 212 & 0.149 & 0.131 & 0.125 \\
\hline & & $\mathrm{Y}+0$ & 212 & 0.109 & 0.104 & 0.107 \\
\hline & & $Y+1$ & 212 & -0.85 & 0.088 & 13.624 \\
\hline & & $\mathrm{Y}+2$ & 212 & -0.875 & 0.078 & 13.686 \\
\hline & \multirow{4}{*}{ Cold } & $Y-1$ & 91 & 0.14 & 0.128 & 0.098 \\
\hline & & $\mathrm{Y}+0$ & 91 & 0.122 & 0.113 & 0.082 \\
\hline & & $\mathrm{Y}+1$ & 91 & 0.106 & 0.106 & 0.093 \\
\hline & & $Y+2$ & 91 & 0.097 & 0.101 & 0.107 \\
\hline \multirow{8}{*}{$\mathrm{CF} / \mathrm{TA}$} & \multirow{4}{*}{ Hot } & $\mathrm{Y}-1$ & 212 & 0.017 & 0.001 & 0.187 \\
\hline & & $\mathrm{Y}+0$ & 212 & -0.181 & -0.044 & 0.954 \\
\hline & & $Y+1$ & 212 & -1.078 & 0.001 & 15.259 \\
\hline & & $\mathrm{Y}+2$ & 212 & -1.014 & 0.015 & 15.308 \\
\hline & \multirow{4}{*}{ Cold } & $\mathrm{Y}-1$ & 91 & 0.029 & 0.033 & 0.149 \\
\hline & & $\mathrm{Y}+0$ & 91 & -0.023 & 0.001 & 0.171 \\
\hline & & $\mathrm{Y}+1$ & 91 & 0.026 & 0.04 & 0.117 \\
\hline & & $\mathrm{Y}+2$ & 91 & 0.021 & 0.025 & 0.139 \\
\hline \multirow{8}{*}{ Size } & \multirow{4}{*}{ Hot } & $Y-1$ & 212 & 11670.13 & 614.1 & 56660.77 \\
\hline & & $\mathrm{Y}+0$ & 212 & 14837.93 & 882.8 & 68236.12 \\
\hline & & $\mathrm{Y}+1$ & 212 & 17597.39 & 1038.2 & 78952.73 \\
\hline & & $\mathrm{Y}+2$ & 212 & 21609.64 & 1238.75 & 95567.73 \\
\hline & \multirow{4}{*}{ Cold } & $Y-1$ & 91 & 96166.73 & 1253 & 245044.8 \\
\hline & & $\mathrm{Y}+0$ & 91 & 115431.8 & 2455.3 & 281860.8 \\
\hline & & $\mathrm{Y}+1$ & 91 & 134182.2 & 3061.4 & 323627.4 \\
\hline & & $\mathrm{Y}+2$ & 91 & 168347.1 & 3771.7 & 397310.3 \\
\hline \multirow{8}{*}{ Sgrowth } & \multirow{4}{*}{ Hot } & $\mathrm{Y}-1$ & 212 & 634.476 & 203.4 & 1533.465 \\
\hline & & $\mathrm{Y}+0$ & 212 & 525.197 & 106.4 & 1696.282 \\
\hline & & $\mathrm{Y}+1$ & 212 & 624.141 & 39.25 & 1933.943 \\
\hline & & $Y+2$ & 212 & 763.69 & 22.3 & 3124.025 \\
\hline & \multirow{4}{*}{ Cold } & $\mathrm{Y}-1$ & 91 & 1173.81 & 158.6 & 3568.743 \\
\hline & & $\mathrm{Y}+0$ & 91 & 2912.806 & 361.1 & 11502.85 \\
\hline & & $\mathrm{Y}+1$ & 91 & 2371.187 & 376.9 & 7222.978 \\
\hline & & $\mathrm{Y}+2$ & 91 & 4341.193 & 321.7 & 14256.71 \\
\hline \multirow{8}{*}{$\mathrm{D} / \mathrm{E}$} & \multirow{4}{*}{ Hot } & $Y-1$ & 212 & 0.642 & 0.33 & 0.971 \\
\hline & & $\mathrm{Y}+0$ & 212 & 0.384 & 0.19 & 0.671 \\
\hline & & $\mathrm{Y}+1$ & 212 & 0.529 & 0.235 & 0.747 \\
\hline & & $\mathrm{Y}+2$ & 212 & 0.808 & 0.29 & 2.814 \\
\hline & \multirow{4}{*}{ Cold } & $Y-1$ & 91 & 4.527 & 0.45 & 30.836 \\
\hline & & $\mathrm{Y}+0$ & 91 & 0.955 & 0.29 & 3.384 \\
\hline & & $\mathrm{Y}+1$ & 91 & 1.201 & 0.33 & 4.045 \\
\hline & & $\mathrm{Y}+2$ & 91 & 0.894 & 0.56 & 1.125 \\
\hline \multirow{8}{*}{ Current } & & $\mathrm{Y}-1$ & 212 & 14.669 & 2.13 & 74.356 \\
\hline & $\mathrm{Hot}$ & $\mathrm{Y}+0$ & 212 & 10.131 & 2.63 & 40.643 \\
\hline & пणा & $\mathrm{Y}+1$ & 212 & 5.6575 & 2.18 & 12.431 \\
\hline & & $\mathrm{Y}+2$ & 212 & 8.822 & 1.85 & 34.833 \\
\hline & & $Y-1$ & 91 & 7.697 & 1.93 & 28.012 \\
\hline & Cold & $\mathrm{Y}+0$ & 91 & 3.444 & 2.41 & 4.373 \\
\hline & Cora & $\mathrm{Y}+1$ & 91 & 2.81 & 2.09 & 2.307 \\
\hline & & $\mathrm{Y}+2$ & 91 & 2.487 & 1.98 & 2.38 \\
\hline & & $\mathrm{Y}+0$ & 212 & 30.198 & 10.03 & 107.727 \\
\hline & Hot & $\mathrm{Y}+1$ & 212 & 17.385 & 9.76 & 63.457 \\
\hline $\mathrm{P} / \mathrm{F}$ & & $\mathrm{Y}+2$ & 212 & 19.354 & 6.55 & 62.91 \\
\hline //L & & $\mathrm{Y}+0$ & 91 & 38.715 & 12.705 & 130.319 \\
\hline & Cold & $\mathrm{Y}+1$ & 91 & 20.51 & 12.595 & 36.135 \\
\hline & & $\mathrm{Y}+2$ & 91 & 41.406 & 10.69 & 187.296 \\
\hline & & $\mathrm{Y}+0$ & 212 & 1.696 & 1.06 & 1.684 \\
\hline $\mathrm{P} / \mathrm{B}$ & Hot & $\mathrm{Y}+1$ & 212 & 1.614 & 0.99 & 1.762 \\
\hline & & $\mathrm{Y}+2$ & 212 & 1.178 & 0.61 & 1.533 \\
\hline & Cold & $\mathrm{Y}+0$ & 91 & 2.6 & 1.78 & 3.256 \\
\hline
\end{tabular}


Table 3 (cont.). Summary statistics

\begin{tabular}{|c|c|c|c|c|c|c|}
\hline Variables & Market condition & Time window & $n$ & Mean & Median & S.D. \\
\hline & & $Y+1$ & 91 & 2.579 & 1.89 & 2.631 \\
\hline & & $Y+2$ & 91 & 2.385 & 1.58 & 2.618 \\
\hline \multirow{6}{*}{ EPS } & \multirow{3}{*}{ Hot } & $Y+0$ & 212 & 6.518 & 3.02 & 9.093 \\
\hline & & $\mathrm{Y}+1$ & 212 & 6.738 & 2.81 & 10.927 \\
\hline & & $Y+2$ & 212 & 6.395 & 2.17 & 13.767 \\
\hline & \multirow{3}{*}{ Cold } & $Y+0$ & 91 & 12.353 & 6.365 & 17.118 \\
\hline & & $Y+1$ & 91 & 13.071 & 7.25 & 15.519 \\
\hline & & $Y+2$ & 91 & 12.23 & 7.52 & 16.312 \\
\hline
\end{tabular}

Post issue market expectations and earning potentials. Hypothesis $H \mathrm{H}$ (a) required us to test whether expectations and earning potentials significantly decline in post IPO period or not. Median raw and industry-adjusted changes in levels of ratios for the Years +1 to +2 relative to Year 0 are reported in Table 4. Median change in P/E is -46.13 for first time window and -68.37 for second time window (significant at 0.01 level). Similarly, median change in
$\mathrm{M} / \mathrm{B}$ is -56.76 for first time window (significant at 0.01 level) and -67.71 for second time window (significant at 0.01 level). The results suggest that there is a significant decline in $\mathrm{P} / \mathrm{E}$ and $\mathrm{M} / \mathrm{B}$ ratio for each time window before and after industry adjustment. It can be seen that the median raw and industry-adjusted EPS of IPO firms also decline significantly in each year relative to Year 0. Hence, the results support our hypothesis $H 1$ (a).

Table 4. Median change in market expectations and earnings potential of Indian firms around their IPO

\begin{tabular}{|c|c|c|}
\hline Variables & Median change (\%) from $Y+0$ to $Y+1$ & Median change (\%) from $Y+0$ to $Y+2$ \\
\hline$P / E$ & $\begin{array}{c}-46.13 \\
(0.76) \\
\end{array}$ & $\begin{array}{c}-68.37^{\star \star *} \\
(3.09)\end{array}$ \\
\hline Industry adjusted P/E & $\begin{array}{c}-48.33^{*} \\
(-0.29)\end{array}$ & $\begin{array}{c}-57.32^{\star} \\
(-1.57)\end{array}$ \\
\hline$M / B$ & $\begin{array}{c}-56.76^{\star \star \star} \\
(2.64)\end{array}$ & $\begin{array}{c}-67.71^{\star * *} \\
(3.26)\end{array}$ \\
\hline Industry adjusted M/B & $\begin{array}{c}-52.21^{\star *} \\
(-0.38)\end{array}$ & $\begin{array}{c}-66.34^{\star * *} \\
(-1.28) \\
\end{array}$ \\
\hline EPS & $\begin{array}{c}-2.66 \\
(1.20)\end{array}$ & $\begin{array}{c}-3.38 \\
(0.684)\end{array}$ \\
\hline Industry adjusted EPS & $\begin{array}{l}6.74^{* *} \\
(-2.32)\end{array}$ & $\begin{array}{l}-9.10^{*} \\
(-1.49)\end{array}$ \\
\hline
\end{tabular}

Notes: The sign $* * *, * *$ and $*$ indicate significant at $1 \%, 5 \%$ and $10 \%$, respectively.

Post issue operating performance. In order to test hypothesis $\mathrm{H} 1(b)$, operating performance of firms in pre IPO period is compared with operating performance in post IPO period. The median changes (percentage) in the performance variables of Indian firms around their IPOs for each of the following three time windows was calculated: (1) one year before IPO (Y-1) to IPO year $(\mathrm{Y}+0),(2)$ one year before IPO (Y-1) to one year after IPO $(\mathrm{Y}+1)$, and (3) one year before IPO $(\mathrm{Y}-1)$ to two year after IPO $(\mathrm{Y}+2)$. The results are reported in Table 5.

Table 5. Median changes in performance variables of Indian public firms around their IPOs

\begin{tabular}{|c|c|c|c|}
\hline Performance variables & Median change $(\%)$ from $Y-1$ to $Y+0$ & Median change (\%) from $Y-1$ to $Y+1$ & Median change (\%) from $Y-1$ to $Y+2$ \\
\hline CF/TA & $\begin{array}{c}-19.946^{* *} \\
(1.67)\end{array}$ & $\begin{array}{c}-49.386^{\star \star \star} \\
(4.45)\end{array}$ & $\begin{array}{c}-57.226^{*} \\
(0.32)\end{array}$ \\
\hline Industry adjusted CF/TA & $\begin{array}{l}-33.302^{*} \\
(-1.23)\end{array}$ & $\begin{array}{l}-48.237^{\star} \\
(-0.29)\end{array}$ & $\begin{array}{c}-59.321^{* *} \\
(-1.57)\end{array}$ \\
\hline PBDIT/TA & $\begin{array}{l}-2.736^{*} \\
(1.32)\end{array}$ & $\begin{array}{c}-20.906^{\star \star \star} \\
(4.33)\end{array}$ & $\begin{array}{c}-39.327^{\star \star \star} \\
(6.80)\end{array}$ \\
\hline Industry adjusted PBDIT/TA & $\begin{array}{l}-8.265^{* *} \\
(-3.10)\end{array}$ & $\begin{array}{c}-12.214^{* *} \\
(-0.38)\end{array}$ & $\begin{array}{c}-36.343^{* * *} \\
(-1.28)\end{array}$ \\
\hline SALES & $\begin{array}{l}41.409^{\star \star \star} \\
(-7.61)\end{array}$ & $\begin{array}{c}88.040^{\star \star *} \\
(-8.24)\end{array}$ & $\begin{array}{c}109.622^{\star \star \star} \\
(-7.78)\end{array}$ \\
\hline Industry adjusted Sales/TA & $\begin{array}{c}28.12^{* \star *} \\
(-3.61)\end{array}$ & $\begin{array}{l}56.74^{* *} \\
(-2.32)\end{array}$ & $\begin{array}{l}99.41^{*} \\
(-1.49)\end{array}$ \\
\hline Capital expenditure & $\begin{array}{c}57.993^{* * *} \\
(-4.72)\end{array}$ & $\begin{array}{c}138.844^{* * *} \\
(-5.81)\end{array}$ & $\begin{array}{c}138.191^{\star * \star} \\
(-5.92)\end{array}$ \\
\hline $\begin{array}{l}\text { Industry adjusted capital } \\
\text { expenditure }\end{array}$ & $\begin{array}{l}47.507^{\star \star \star} \\
(-3.17)\end{array}$ & $\begin{array}{c}152.649^{\star \star \star *} \\
(-4.17)\end{array}$ & $\begin{array}{c}125.520^{\star \star \star *} \\
(-3.65)\end{array}$ \\
\hline
\end{tabular}

Notes: The sign $* * *, * *$ and $*$ indicate significant at $1 \%, 5 \%$ and $10 \%$, respectively. 
The median changes in $(C F / T A)$ from $\mathrm{Y}-1$ to $\mathrm{Y}+0$, $\mathrm{Y}+1$ and $\mathrm{Y}+2$ were, respectively, -19.946 percent, -49.386 percent and -57.226 percent (all significantly different from zero at $0.05,0.01$ and 0.10 levels, respectively). The median changes in industry adjusted (CF/TA) were, respectively, -33.302 percent, -48.237 percent and -59.321 percent (all significantly different from zero at 0.10, 0.10 and 0.05 levels, respectively). Hence, the decline in CF/TA can not be attributed to industry effect.

The median changes in (PBDIT/TA) from $\mathrm{Y}-1$ to $\mathrm{Y}+0, \mathrm{Y}+1$ and $\mathrm{Y}+2$ were, respectively, -2.736 percent, -20.906 percent and -39.327 percent (all significantly different from zero). The decline cannot be attributed to industry effect as the industry adjusted (PBDIT/TA) shows a similar decline for all the time windows.

\section{Do Hot Issue Markets reflect timing attempts?}

A dummy variable $H O T$ was constructed to test the hypothesis $H 1$ (c). The discussion on measurement of this dummy variable is already discussed in the methodology section. The variable is kept as one of the independent variables in the model.

Table 6 ( $a \& b$ ). Market Timing Effects on Issuance Activity

Table 6 (a). Mean values

\begin{tabular}{|l|c|c|}
\hline & $\begin{array}{c}\text { Total Proceeds } \\
\text { (Rs. Million) }\end{array}$ & Total Proceeds/Total Assets \\
\hline Hot & 3219.679 & 0.352 \\
\hline Cold & 1469.219 & 0.226 \\
\hline -statistics & $1.5413^{*}$ & $-4.672^{\star * *}$ \\
\hline
\end{tabular}

Notes: The sign $* * *, * *$ and $*$ indicate significant at $1 \%, 5 \%$ and $10 \%$, respectively.
Table 6 (b). Relationship between market timing and total proceeds of the firms

\begin{tabular}{|l|c|c|}
\hline \multicolumn{1}{|c|}{ Variable } & Model 1 & Model 2 \\
\hline \multirow{2}{*}{ HOT } & $339.08^{\star}$ & $134.542^{\star *}$ \\
& $(225.19)$ & $(239.596)$ \\
\hline \multirow{2}{*}{ Size } & $-0.048^{\star}$ & $-0.167^{\star \star}$ \\
& $(.071)$ & $(0.061)$ \\
\hline \multirow{2}{*}{ PBDIT } & 0.627 & $-1.074^{* \star}$ \\
& $(0.568)$ & $(0.502)$ \\
\hline \multirow{2}{*}{ Sgrw } & $0.269^{\star \star \star}$ & $0.383^{* \star \star}$ \\
& $(0.095)$ & $(0.115)$ \\
\hline \multirow{2}{*}{ Intang } & $1.951^{\star \star *}$ & -2.875 \\
& $(0.447)$ & $(3.245)$ \\
\hline \multirow{2}{*}{ D/E } & 194.021 & -49.748 \\
& $(405.578)$ & $(423.029)$ \\
\hline \multirow{2}{*}{ M/B } & $208.820^{\star \star *}$ & $277.221^{* \star *}$ \\
& $(113.726)$ & $(80.534)$ \\
\hline \multirow{2}{*}{ Constant } & -99.943 & 32.286 \\
& $(299.143)$ & $(198.714)$ \\
\hline Obs & 306 & 306 \\
\hline Adjusted R & 0.864 & 0.767 \\
\hline
\end{tabular}

Notes: The sign $* * *, * *$ and $*$ indicate significant at $1 \%, 5 \%$ and $10 \%$, respectively.

Table 6 shows the mean values of total proceeds and Proceeds/Total Assets for Hot- versus Cold-Market firms. The statistics indicate that Hot Issue Market firms sell substantially more equity than do ColdMarket firms. For example, proceeds from the sale of primary shares are on average 228.381 in Hot Issue Market as compared to 220.858 in Cold Market. Ratio of total proceeds and total assets shows a significant difference in terms of proceeds raised in Hot Issue Market as compared to that of Cold Market. Where the ratio is 156.375 in Hot Issue Market, it is 67.806 in Cold Market. The independent $\mathrm{t}$-test shows that the difference in mean is significant.

Table 7 (a \& b). Market Timing Effects on operating performance of firms

Table 7 (a). Comparison of Hot and Cold Market firms

\begin{tabular}{|l|c|c|c|c|c|c|c|c|}
\hline & \multicolumn{4}{|c|}{ PBDIT/A } & \multicolumn{4}{c|}{ CF/A $t$} \\
\hline$t$ & $\mathrm{IPO}-1$ & $\mathrm{IPO}$ & $\mathrm{IPO}+1$ & $\mathrm{IPO}+2$ & $\mathrm{IPO}-1$ & $\mathrm{IPO}$ & $\mathrm{IPO}+1$ & $\mathrm{IPO}+2$ \\
\hline Hot & 0.149 & 0.109 & -0.850 & -0.875 & 0.017 & -0.181 & -1.078 & -1.014 \\
\hline Cold & 0.140 & 0.122 & .106 & 0.097 & 0.029 & -0.023 & 0.026 & 0.021 \\
\hline $\mathrm{t}$-value & -0.543 & -0.905 & -0.578 & -0.581 & -0.496 & $-1.345^{\star}$ & -0.596 & -0.553 \\
\hline
\end{tabular}

Table 7 (b). Regression analysis

\begin{tabular}{|c|c|c|c|c|c|c|c|c|}
\hline & \multicolumn{4}{|c|}{$P B D I T / A_{t}$} & \multicolumn{4}{|c|}{$C F / A_{t}$} \\
\hline & IPO-1 & IPO & $\mathrm{IPO}+1$ & $\mathrm{IPO}+2$ & IPO-1 & IPO & $\mathrm{IPO}+1$ & $\mathrm{IPO}+2$ \\
\hline Hot & $\begin{array}{l}-0.002 \\
(0.016)\end{array}$ & $\begin{array}{l}-0.018^{*} \\
(0.012)\end{array}$ & $\begin{array}{l}-0.022 \\
(0.030)\end{array}$ & $\begin{array}{l}-0.023 \\
(0.028)\end{array}$ & $\begin{array}{c}0.036 \\
(0.064)\end{array}$ & $\begin{array}{l}-0.043 \\
(0.05)\end{array}$ & $\begin{array}{r}-0.177 \\
(0.14)\end{array}$ & $\begin{array}{l}-0.006 \\
(0.02)\end{array}$ \\
\hline Size & $\begin{array}{l}-0.001^{*} \\
(0.001)\end{array}$ & $\begin{array}{c}-0.001^{\star * \star} \\
(0.001)\end{array}$ & $\begin{array}{c}-0.001^{* \star \star} \\
(0.001)\end{array}$ & $\begin{array}{c}-0.001^{* \star \star} \\
(0.001)\end{array}$ & $\begin{array}{l}-0.001 \\
(0.001)\end{array}$ & $\begin{array}{l}0.001 \\
(0.00)\end{array}$ & $\begin{array}{c}-0.001^{* *} \\
(0.00)\end{array}$ & $\begin{array}{l}-0.001 \\
(0.00)\end{array}$ \\
\hline Sgrowth & $\begin{array}{c}0.001 \\
(0.001)\end{array}$ & $\begin{array}{c}0.001^{\star \star \star} \\
(0.001)\end{array}$ & $\begin{array}{c}0.001^{* * *} \\
(0.001)\end{array}$ & $\begin{array}{l}0.001^{* \star *} \\
(0.001)\end{array}$ & $\begin{array}{c}0.001 \\
(0.000)\end{array}$ & $\begin{array}{l}0.001 \\
(0.00)\end{array}$ & $\begin{array}{c}0.001^{* *} \\
(0.00)\end{array}$ & $\begin{array}{l}0.001^{*} \\
(0.00)\end{array}$ \\
\hline $\mathrm{D} / \mathrm{E}$ & $\begin{array}{c}-0.025^{\star \star \star} \\
(0.005)\end{array}$ & $\begin{array}{l}-0.014^{*} \\
(0.009)\end{array}$ & $\begin{array}{l}-0.004 \\
(0.013)\end{array}$ & $\begin{array}{c}0.010 \\
(0.011)\end{array}$ & $\begin{array}{l}-0.020 \\
(0.018)\end{array}$ & $\begin{array}{l}0.007 \\
(0.04)\end{array}$ & $\begin{array}{l}0.078 \\
(0.12)\end{array}$ & $\begin{array}{l}-0.017 \\
(0.01)\end{array}$ \\
\hline Curr & $\begin{array}{c}0.001 \\
(0.001)\end{array}$ & $\begin{array}{c}0.003^{\star \star *} \\
(0.000)\end{array}$ & $\begin{array}{c}-0.001^{* * *} \\
(0.006)\end{array}$ & $\begin{array}{c}-0.001^{* * *} \\
(0.000)\end{array}$ & $\begin{array}{c}0.001 \\
(0.002)\end{array}$ & $\begin{array}{c}-0.005^{\star \star *} \\
(0.00)\end{array}$ & $\begin{array}{l}0.002 \\
(0.01)\end{array}$ & $\begin{array}{l}-0.002^{*} \\
(0.00)\end{array}$ \\
\hline
\end{tabular}


Table 7 (b) (cont.). Regression analysis

\begin{tabular}{|l|c|c|c|c|c|c|c|c|}
\hline & \multicolumn{4}{|c|}{$P B D I T / A_{t}$} & \multicolumn{4}{c|}{$C F / A_{t}$} \\
\hline & $\mathrm{IPO}-1$ & $\mathrm{IPO}$ & $\mathrm{IPO}+1$ & $\mathrm{IPO}+2$ & $\mathrm{IPO}-1$ & $\mathrm{IPO}$ & $\mathrm{IPO}+1$ & $\mathrm{IPO}+2$ \\
\hline \multirow{2}{*}{ Constant } & 0.189 & 0.139 & 0.113 & 0.090 & 0.034 & -0.040 & 0.007 & 0.038 \\
& $(0.017)$ & $(0.011)$ & $(0.028)$ & $(0.027)$ & $(0.058)$ & $(0.03)$ & $(0.06)$ & $(0.02)$ \\
\hline Obs & 303 & 303 & 303 & 303 & 303 & 303 & 303 & 303 \\
\hline Adjusted R & 0.45 & 0.80 & 0.56 & 0.24 & 0.14 & 0.17 & 0.16 & 0.16 \\
\hline
\end{tabular}

Table 8 (a \& b). Market Timing Effects on investors' expectations and earning potentials

Table 8 (a). Comparison of Hot and Cold Market firms

\begin{tabular}{|l|c|c|c|c|c|c|c|c|c|}
\hline & \multicolumn{3}{|c|}{ P/E } & \multicolumn{3}{|c|}{ P/B } & \multicolumn{3}{c|}{ EPS } \\
\hline$t$ & IPO & IPO+1 & IPO+2 & IPO & IPO+1 & IPO+2 & IPO & IPO+1 & IPO+2 \\
\hline Hot & 30.198 & 17.385 & 19.354 & 1.696 & 1.614 & 1.178 & 6.518 & 6.738 & 6.395 \\
\hline Cold & 10.917 & 20.519 & 41.406 & 2.600 & 2.579 & 2.385 & 12.353 & 13.071 & 12.230 \\
\hline$t$-value & $-2.129^{* *}$ & 0.368 & $1.388^{*}$ & $2.793^{* *}$ & $3.264^{* *}$ & $4.426^{* \star *}$ & $-3.723^{* *}$ & $-3.800^{* *}$ & $-2.948^{* *}$ \\
\hline
\end{tabular}

The Hot Issue Market effect on the amount of equity issued can potentially be due to differing characteristics of Hot- versus Cold-Market firms. To address this, a multivariate regression is estimated. Table 7 shows the result of the regression. The results confirm that the tendency of Hot Issue Market firms to issue more equity is a genuine timing effect. The relationship between HOT and total proceeds is positive and significant for both the models. Various firm characteristics are significant determinants of equity issuance activity. The relationship between Size and total proceeds is negative and significant in both the models indicating that bigger size firms tend to raise lesser proceeds from IPO. The result goes well with the signalling explanation of underpricing. The relationship between PBDIT/TA and total proceeds is positive overall (model 1), whereas it is negative when industry level variation is taken into account (model 2). Relationship between Sgrw and total proceeds is positive and significant in both the models. Asset risk (Intang) appears to be negatively related to issuance activity. The relationship is negative in both the models, but significant in only model 1 . The relationship between leverage and total proceeds is negative and significant in both the models. The relationship between market-to-book ratio (M/B) and total proceeds is significant in model 1 only. The relationship is positive suggesting more is the overvaluation more is the total proceeds.

Table 8 (b). Regression analysis

\begin{tabular}{|c|c|c|c|c|c|c|c|c|c|}
\hline & \multicolumn{3}{|c|}{$P / E$} & \multicolumn{3}{|c|}{$P / B$} & \multicolumn{3}{|c|}{ EPS } \\
\hline & IPO & $\mathrm{IPO}+1$ & $\mathrm{IPO}+2$ & IPO & $\mathrm{IPO}+1$ & $\mathrm{IPO}+2$ & IPO & $\mathrm{IPO}+1$ & $\mathrm{IPO}+2$ \\
\hline Hot & $\begin{array}{l}-18.973 \\
(22.39) \\
\end{array}$ & $\begin{array}{c}-2788.84 \\
(2778.02) \\
\end{array}$ & $\begin{array}{l}-26.41 \\
(32.37)\end{array}$ & $\begin{array}{c}-0.605^{\star *} \\
(0.325)\end{array}$ & $\begin{array}{c}-0.617^{* *} \\
(0.32)\end{array}$ & $\begin{array}{l}-0.86^{* *} \\
(0.33)\end{array}$ & $\begin{array}{c}-2.802^{*} \\
(1.97)\end{array}$ & $\begin{array}{l}-3.66^{* *} \\
(2.04)\end{array}$ & $\begin{array}{l}-2.448 \\
(2.41)\end{array}$ \\
\hline PBDIT/TA & $\begin{array}{c}-108.80^{*} \\
(81.31) \\
\end{array}$ & $\begin{array}{c}-2627.18 \\
(2855.21) \\
\end{array}$ & $\begin{array}{c}2.645 \\
(17.35)\end{array}$ & $\begin{array}{c}3.617^{\star \star *} \\
(1.15)\end{array}$ & $\begin{array}{l}1.772^{*} \\
(1.09)\end{array}$ & $\begin{array}{c}2.067^{\star *} \\
(0.85)\end{array}$ & $\begin{array}{l}49.89^{\star \star \star *} \\
(13.68)\end{array}$ & $\begin{array}{l}0.246 \\
(0.85)\end{array}$ & $\begin{array}{c}32.30^{\star \star \star} \\
(6.07)\end{array}$ \\
\hline $\mathrm{CF} / \mathrm{TA}$ & $\begin{array}{c}13.159^{* *} \\
(6.35)\end{array}$ & $\begin{array}{c}43.231 \\
(46.464)\end{array}$ & $\begin{array}{l}30.062 \\
(39.86)\end{array}$ & $\begin{array}{l}0.181^{* *} \\
(0.102)\end{array}$ & $\begin{array}{c}0.095^{\star *} \\
(0.04)\end{array}$ & $\begin{array}{c}-0.079 \\
(0.97)\end{array}$ & $\begin{array}{c}1.477^{\star *} \\
(0.65)\end{array}$ & $\begin{array}{l}-0.188 \\
(0.76)\end{array}$ & $\begin{array}{c}-28.83^{\star \star} \\
(5.42)\end{array}$ \\
\hline Size & $\begin{array}{l}0.001 \\
(0.00)\end{array}$ & $\begin{array}{l}0.016 \\
(0.01)\end{array}$ & $\begin{array}{l}0.003 \\
(0.00)\end{array}$ & $\begin{array}{c}-0.001^{\star *} \\
(0.00)\end{array}$ & $\begin{array}{c}-0.001^{* *} \\
(0.00)\end{array}$ & $\begin{array}{c}-0.004^{*} \\
(0.00)\end{array}$ & $\begin{array}{l}0.002 \\
(0.00)\end{array}$ & $\begin{array}{l}-0.01^{* *} \\
(0.00)\end{array}$ & $\begin{array}{l}-0.001 \\
(0.00)\end{array}$ \\
\hline Sgrowth & $\begin{array}{l}-0.002 \\
(0.00)\end{array}$ & $\begin{array}{l}-0.227 \\
(0.24)\end{array}$ & $\begin{array}{c}-0.002 \\
(0.00)\end{array}$ & $\begin{array}{c}0.002^{\star * \star} \\
(0.00)\end{array}$ & $\begin{array}{c}0.002^{\star \star \star} \\
(0.00)\end{array}$ & $\begin{array}{c}0.01^{* \star *} \\
(0.00)\end{array}$ & $\begin{array}{c}0.004^{* *} \\
(0.00)\end{array}$ & $\begin{array}{l}0.01^{* * *} \\
(0.00)\end{array}$ & $\begin{array}{l}0.002^{*} \\
(0.00)\end{array}$ \\
\hline$D / E$ & $\begin{array}{r}-10.594 \\
(10.66) \\
\end{array}$ & $\begin{array}{l}-517.21 \\
(527.07) \\
\end{array}$ & $\begin{array}{l}0.394 \\
(1.87) \\
\end{array}$ & $\begin{array}{l}-0.077 \\
(0.22) \\
\end{array}$ & $\begin{array}{l}0.009 \\
(0.18) \\
\end{array}$ & $\begin{array}{c}0.045^{\star *} \\
(0.01) \\
\end{array}$ & $\begin{array}{l}4.114^{*} \\
(2.81) \\
\end{array}$ & $\begin{array}{l}2.143^{*} \\
(1.34) \\
\end{array}$ & $\begin{array}{c}-1.25^{\star \star \star} \\
(0.34) \\
\end{array}$ \\
\hline Curr & $\begin{array}{c}2.580^{* * *} \\
(0.05)\end{array}$ & $\begin{array}{l}-25.286 \\
(29.25)\end{array}$ & $\begin{array}{l}-0.094 \\
(0.07)\end{array}$ & $\begin{array}{c}-0.001^{*} \\
(0.00)\end{array}$ & $\begin{array}{c}-0.019^{* *} \\
(0.00)\end{array}$ & $\begin{array}{c}-0.03^{\star *} \\
(0.00)\end{array}$ & $\begin{array}{l}-0.006 \\
(0.00)\end{array}$ & $\begin{array}{c}-0.10^{\star \star} \\
(0.03)\end{array}$ & $\begin{array}{c}-0.038^{\star \star} \\
(0.01)\end{array}$ \\
\hline Constant & $\begin{array}{l}52.231 \\
(34.57) \\
\end{array}$ & $\begin{array}{c}3503.53 \\
(3467.87)\end{array}$ & $\begin{array}{l}46.471 \\
(30.97)\end{array}$ & $\begin{array}{c}1.972 \\
(0.342) \\
\end{array}$ & $\begin{array}{l}2.160 \\
(0.35) \\
\end{array}$ & $\begin{array}{l}1.920 \\
(0.31) \\
\end{array}$ & $\begin{array}{l}3.207 \\
(2.35) \\
\end{array}$ & $\begin{array}{l}9.820 \\
(2.06)\end{array}$ & $\begin{array}{l}9.374 \\
(2.25) \\
\end{array}$ \\
\hline Obs & 303 & 303 & 303 & 303 & 303 & 303 & 303 & 303 & 303 \\
\hline Adjusted R² & 0.53 & 0.27 & 0.40 & 0.46 & 0.28 & 0.27 & 0.32 & 0.18 & 0.18 \\
\hline
\end{tabular}

\section{Conclusion}

Results on earning potentials like $\mathrm{P} / \mathrm{E}$ and $\mathrm{M} / \mathrm{B}$ and earnings like EPS suggest that investors' expectations about firms' growth were not even sustained. The constant decline in $\mathrm{P} / \mathrm{E}$ and $\mathrm{M} / \mathrm{B}$ suggest that firms took advantage of over-optimism of investors. The decline in earnings in post IPO period is in support of Ritter (1991), Jain and Kini (1994) and Loughran and Ritter (1995).

The expectation about future earnings is most of the times formed on the basis of pre IPO profit margin. The results supported the argument given by Jain 
and Kini (1994) that firms do IPO when their profitability level is high, and which they are sure they would not be able to sustain in the future. Study has found that overall performance of firms deteriorates significantly in post IPO period. As compared to PBDIT/TA, the decrease was sharper for CF/TA. Industry adjusted performance measures recorded the same result and, hence, negate the reason of this decrease to be an industry effect.

One can argue that decrease in post IPO performance could be because of lack of sales and investment opportunities in post IPO period. Therefore, the study examined the trend in sales and capital expenditure around IPO. The results suggested that the sales and capital expenditure increased considerably in post IPO period. Therefore, I cannot say that decrease in post IPO performance was because of lack of sales and investment opportunities or cutback in capital expenditure in post IPO period. One can also argue that the effect of IPO could not be seen in mere one or two year after IPO. The estimations could have been done for more time windows, but the nonavailability of data has restricted our study to examine the relationship till two year after IPO. I expect that, in future, the study could further be extended by taking longer time duration into the effect.

In order to see whether the IPOs were timed with favorable Market or not the Market was divided into Hot and Cold Market, defined on the basis of the monthly IPO volume. Then, the relationship between Market type and total proceeds was established with the help of multivariate regression model with the idea that any timing attempt should be reflected in the activity of issuance of equity. The result based on multivariate regression suggest that Market timers, identified as firms that go public when the market is Hot, tried to maximize the total proceeds at the time of IPO. The Hot Issue Market effect is remarkably robust; it is significant for both firm and industry-level characteristics.

\section{References}

1. Aggarwal, R. (2000). Stabilization Activities by Underwriters after Initial Public Offerings, Journal of Finance, 55(3), pp. 1075-1103.

2. Agarwal, S., Liu, C.L. and Rhee, S.G. (2008). Investor Demand for IPOs and Aftermarket Performance: Evidence from the Hong Kong Stock Market, Journal of International Financial Markets, Institutions \& Money, 18(2), pp. 176-190.

3. Allen F. and G. Faulhaber (1989). Signaling by underpricing in the IPO market, Journal of Financial Economics, 23, pp. 303-23.

4. Alti, A. (2006). How Persistent Is the Impact of Market Timing on Capital Structure, Journal of Finance, 61(4), pp. 1681-1710.

5. Brailsford, T., Heaney, R. \& Shi, J. (2004). Modelling the behavior of the new issue market, International Review of Financial Analysis, 13, pp. 119-132.

6. Coakley, J., Hadass, L. and Wood, A. (2004). Post-IPO operating performance, venture capitalists and market timing, discussion paper no. 04-16, University Essex.

7. Cook, D., Jarrell, S., Kieschnick, R. (2003). Investor sentiment and IPO cycles, Unpublished Working Paper, University of Mississippi.

8. Derrien, François. (2005). IPO pricing in "hot" market conditions: Who leaves money on the table? Journal of Finance, 60, pp. 487-521.

9. Ghosh, S. (2004). Boom and Slump Periods in the Indian IPO Market, Reserve Bank of India Occasional Papers, 25 , pp. 39-56.

10. He, P. (2007). A theory of IPO waves, Review of Financial Studies, 20(4), pp. 983-1020.

11. Helwege, J. and Liang, N. (2004). Initial public offerings in hot and cold markets, Journal of Financial and Quantitative Analysis, 39, pp. 541-569.

12. Hoffmann-Burchardi, Ulrike. (2001). Clustering of initial public offering, information revelation and underpricing, European Economic Review, 45(2), pp. 353-83.

13. Ibbotson, Roger G. and Jeffrey F. Jaffe (1975). Hot issue markets, Journal of Finance, 30, pp. 1027-1042.

14. Ibbotson, Roger G., Jody L. Sindelar, and Jay R. Ritter (1988). Initial public offerings, Journal of Applied Corporate Finance, 1, pp. 37-45.

15. Jaskiewicz P., González, Víctor M., Menéndez, Susana and Schiereck, Dirk. (2005). Long-Run IPO Performance Analysis of German and Spanish Family-Owned Businesses, Family Business Review, 18(3), pp. 179-2002.

16. Jain, Bharat A. and Kini, Omesh. (1994). The post-issue operating performance of IPO firms, Journal of Finance, 49, pp. 1699-1726.

17. Levis, M. (1993). The Long Run Performance of Initial Public Offerings: The UK Experience 1980-1988, Financial Management, 22(1), pp. 28-41.

18. Loughran, Tim and Jay Ritter. (1995).The new issues puzzle, Journal of Finance, 50, pp. 23-51.

19. Lowry, Michelle and G. William Schwert. (2002). IPO market cycles: bubbles or sequential learning, Journal of Finance, 57, pp. 1171-1200. 
20. Marisetty, V. and Subrahmanyam, M. (2008). Group affiliation and the performance of initial public offerings in the Indian stock market, working paper, New York University.

21. Mayur, M. and Kumar, M. (2013). Determinants of Going-Public Decision in an Emerging Market: Evidence from India, Vikalpa: The Journal for Decision Makers, 38(1).

22. McKenzie, M.D. (2007). International evidence on the determinants of the decision to list, Australian Journal of Management, 32(1), pp. 1-28.

23. Rajan, R.G. and L. Zingales. (1995). What Do We Know About Capital Structure? Some evidence from international data, Journal of Finance, 50(5), pp. 1421-1460.

24. Ritter, J. (1984). The Hot Issue Market of 1980, Journal of Business, 57, pp. 215-240.

25. Ritter, J.R. (1991). The Long-Run Performance of Initial Public Offerings, Journal of Finance, 46, pp. 3-27.

26. Sahoo, S. and Rajib, P. (2010). After Market Pricing Performance of Initial Public Offerings (IPOs): Indian IPO Market 2002-2006, Vikalpa, 35(4), pp. 27-44.

27. Titman, S. and Wessels, R. (1988). The determinants of capital structure choice, Journal of Finance, 43, pp. 1-19.

28. Wang, C. (2005). Ownership and operating performance of Chinese IPOs, Journal of Banking and Finance, 29, pp. $1835-1856$. 